\title{
PENAMBAHAN EKSTENDER MADU DALAM PROSES PENYIMPANAN SPERMA BEKU TERHADAP MOTILITAS DAN VIABILITAS SPERMATOZOA IKAN KOMET (Carassius auratus auratus)
}

\section{ADDITIONS EXTENDER HONEY IN FROZEN SPERM STORAGE PROCESS AGAINST SPERM MOTILITY AND VIABILITY COMET FISH (Carassius auratus auratus).}

\author{
Boedi Setya Rahardja, A. Shofy Mubarak dan Permana Sulistyo Rini \\ Fakultas Perikanan dan Kelautan Universitas Airlangga \\ Kampus C Mulyorejo - Surabaya, 60115 Telp. 031-5911451
}

\begin{abstract}
The development of fish culture is strongly influenced by hatchery technology, especially in the stock of fish seed. Often, the problem arises in the stock of seeds, due to the maturation of gametes, broadstock fish sometimes do not happen simultaneously, one of alternative solution to the problem through the application of reproductive biotechnology, is preservation of sperm (Dirjennak, 2007). Preservation sperm is to optimize the male broadstock (Dirjennak, 2007). This storage process requires diluent and cryoprotectant material that could sustain sperm motility (Zaenab, 2007). Diluent material is used to reduce the activity of spermatozoa that inhibit energy usage and prolong the life of sperm (Rustidja, 2000). The use of honey as a diluent material is expected to support the vitality of spermatozoa. Material of honey there are various combinations of materials a simple sugar and salt ions. With the combination of basic ingredients and simple sugar salt ions spermatozoa can produce an energy source so it can defend itself and can fertilize an egg cell after Cryoperservation process.

The purpose of this research is to know the effect of adding extender honey in enhancing sperm motility and viability of fish comet after the freezing process and to determine the best dose of honey in the process of freezing sperm comet fish (Carassius auratus auratus). This research was conducted at the Laboratory Center for Artificial Insemination Singosari. The design use Completely Randomized Design (CRD) followed by Duncan's multiple range test.

Test materials in this research is sperm comet fish are packed in mini straw and stored in liquid nitrogen container with 9 treatments and 3 replications. Media diluent used was physiological $\mathrm{NaCl}$ is added to honey, glucose, fructose, and Tris Aminomethane. Honey dosages of the experiments were $0.3 \%$ (A); $0.4 \%(B), 0.5 \%(C), 0.6 \%(\mathrm{D})$ and $0.7 \%(\mathrm{E})$ and $0.05 \%$ glucose $(\mathrm{KG})$; fructose $0.05 \%$ (KF), Tris Aminomethane (KT) and without the addition of physiological $\mathrm{NaCl}(\mathrm{KN})$. The main parameters of observed percentage of live sperm and duration of motion. The supporting parameters measured were fresh sperm concentration, percentage of live sperm fresh, long fresh sperm, $\mathrm{pH}$, volume and color of sperm.

The results of the research shows that the addition of honey with different dosage at diluents material physiological $\mathrm{NaCl}$ gived significant effect $(\mathrm{P}<0.05)$ against the percentage of sperm motion and long life. Average percentage of long life and highest sperm obtained by treatment of the addition of honey $0.6 \%$ (D), ie $63.89 \%$ and 101.33 seconds. Average lowest percentage of life gained by treatment of honey $0.3 \%$ (C) that were 39.67 second while the lowest was in motion treatment control without the addition of $(\mathrm{KN})$ that were 28.33 seconds.
\end{abstract}

Keywords : Carassius auratus auratus, sperm, honey, cryopreservation

Pendahuluan
Latar Belakang
Perkembangan budidaya ikan sangat
dipengaruhi oleh teknologi pembenihan,
terutama dalam pengadaan benih ikan. Sering
kali timbul masalah dalam pengadaan benih
yang dikarenakan masa pematangan gamet
induk ikan jantan dan betina terkadang tidak
terjadi secara bersamaan, salah satu cara untuk
memberikan alternatif pemecahan dalam masalah tersebut melalui penerapan bioteknologi reproduksi yaitu pengawetan sperma (Dirjennak,2007). Pengawetan sperma bertujuan dalam mengoptimalkan induk jantan yang unggul dalam membuahi sel telur betina yang sejenis sehingga pengawetan sperma mempunyai peran yang sangat besar dalam penyediaan benih ikan unggul (Dirjennak,2007). Ikan komet memiliki pemasaran dan permintaan yang relatif stabil dikarenakan ikan 
komet memiliki bentuk tubuh yang menarik, kombinasi warna yang indah dan selalu bermunculan jenis atau strain yang beragaam. Selain itu ikan ini memiliki ketahanan tubuh yang lebih baik bila dibandingkan dengan ikan hias tawar lainnya sehingga cara pemeliharaanya relatif mudah.

Pengawetan sperma membutuhkan sperma yang baik kualitas dan kuantitasnya, sedangkan kriteria kualitas sperma yang baik untuk proses penyimpanan menurut Toelihere (1981) yaitu sperma dengan motilitas lebih dari $70 \%$ dan lama gerak menurut Fujaya (2002) yaitu lebih dari dua menit. Bentuk teknologi pembekuan semen ini disebut dengan kriopreservasi sperma (Partodiharjo,1992).

Kriopreservasi sperma merupakan suatu teknik penyimpanan semen dan oosit dalam keadaan beku, sedangkan keuntungan dari kriopreservasi sperma ialah sperma dapat disimpan dalam waktu yang tidak terbatas dan dapat digunakan kapan saja bila diperlukan (Toelihere,1981). Proses ini membutuhkan bahan pengencer dan krioprotektan yang dapat mempertahankan motilitas spermatozoa. (Zaenab,2007). Keberhasilan teknik pengawetan spermatozoa ditentukan oleh temperature, pengaturan pertukaran gas, pencegahan pertumbuhan bakteri dan pencegahan terhadap aktifitas gamet (Billard, et al., 1995).

Pemakaian ekstender dimaksudkan untuk mengurangi aktifitas spermatozoa sehingga menghambat pemakaian energi dan memperpanjang hidup spermatozoa (Rustidja,2000). Penggunaan madu sebagai bahan pengencer diharapkan dapat mendukung daya hidup spermatozoa. Hal ini dikarenakan pada madu terdapat berbagai kombinasi bahan dasar gula sederhana dan ion-ion garam. Dengan adanya kombinasi bahan dasar gula sederhana dan ion-ion garam spermatozoa dapat menghasilkan sumber energi sehingga dapat mempertahankan diri dan dapat membuahi sel telur setelah proses Cryoperservation. Penambahan ekstender madu dapat memberikan pengaruh terhadap motilitas dan viabilitas spermatozoa ikan komet setelah proses pembekuan.

\section{Perumusan Masalah}

Berdasarkan latar belakang di atas dapat dirumuskan suatu masalah :

1) Bagaimana pengaruh penambahan ekstender madu dalam meningkatkan motilitas dan viabilitas spermatozoa ikan komet setelah proses pembekuan?
2) Berapakah konsentrasi ekstender madu yang tepat dalam proses pembekuan spermatozoa ikan komet?

Tujuan dilakukan penelitian ini adalah untuk mengetahui pengaruh madu terhadap motilitas dan viabilitas spermatozoa ikan komet pada proses pembekuan dan untuk mengetahui konsentrasi madu yang tepat pada media ekstender agar dapat memberikan daya simpan yang terbaik.

Penelitian ini diharapkan memberikan informasi bermanfaat sebagai bahan pertimbangan tentang pengaruh penambahan ekstender madu dalam meningkatkan motilitas dan viabilitas spermatozoa ikan komet setelah proses pembekuan serta menentukan konsentarsi madu secara tepat pada proses penyimpanan spermatozoa beku ikan.

\section{Metodologi Penelitian \\ Waktu dan Tempat}

Penelitian ini dilaksanakan pada bulan April 2010 di Laboratorium Balai Besar Inseminasi Buatan Singosari, Malang.

\section{Meteri Penelitian}

Materi penelitian yang akan digunakan terdiri atas bahan dan alat penelitian. alat yang digunakan dalam penelitian ini adalah mikroskop, tabung Eppendorf, tabung reaksi, gelas ukur, mini straw, obyek glass, cover glass, thermometer, Erlenmeyer, timbangan analitik, alumuniun foil, counter, cool top cabinet, container nitrogen cair, lap halus, kertas $\mathrm{pH}$, pipet, spuit, haemocytometer, lemari pendingin. Bahan penelitian yang akan digunakan adalah Sperma ikan komet (Carasius auratus auratus), alkohol 70\%, madu, $\mathrm{NaCl}$ fisiologis, Natrium sitrat, glukosa, fruktosa, Tris Amonethane, Nitrogen cair, Penicillin, Streptomicin, gliserol dan larutan eosin negrosin dan aquadest.

\section{Metode Penelitian}

Rancangan penelitian yang digunakan dalam penelitian adalah Rancangan Acak Lengkap (RAL), sebab dalam penelitian ini semua dikondisikan sama kecuali perlakuan yaitu konsentrasi madu, Tris Aminomethane, $\mathrm{NaCl}$, glukosa dan fruktosa sebagai kontrol (Kusriningrum, 2008). Penelitian ini menggunakan media pengencer $\mathrm{NaCl}$ fisiologis yang ditambahkan dengan dosis madu $0,3 \%$ (A); $0,4 \%$ (B); $0,5 \%$ (C); 0,6\% (D); 0,7\% (E); Tris Aminomethane (KT), glukosa 0,05\% (KG); fruktosa $0,05 \%(\mathrm{KF})$ dan tanpa penambahan $(\mathrm{KN})$. 


\section{Prosedur Kerja}

A. Persiapan penelitian

Persiapan penelitian ini meliputi persiapan peralatan dan bahan-bahan yang diperlukan serta menyiapkan induk ikan komet matang gonad yang akan di stripping.

Sterilisasi alat-alat yang digunakan selama penelitian dilakukan dengan cara. Peralatan yang akan digunakan dicuci sampai bersih kemudian dibilas air tawar dan dikeringkan. Peralatan yang terbuat dari kaca tahan panas seperti pipet dan gelas ukur harus dicuci bersih lalu dimasukan ke dalam panci berisi air panas atau direbus dan tiriskan, melakukan pasteurisasi di dalam oven atau inkubator pada suhu $55-60^{\circ} \mathrm{C}$ selama 3-12 jam (Zenichori,dkk. 2007).

B. Pelaksanaan Penelitian

a. Persiapan dan Pembuatan Larutan Pengencer.

Membuat larutan pengencer yang akan digunakan dalam proses pembekuan sebagai berikut: langkah awal adalah persiapan bahan dan alat yang dibutuhkan dalam proses pembuatan larutan pengencer. Bahan dan alat yang dibutuhkan antara lain madu, $\mathrm{NaCl}$ fisiologis, Natrium sitrat, penicillin, streptomicin, glyserol, fuktosa, glukosa dan Tris Aminomethane.

b. Pengambilan Sperma (stripping).

Ikan matang gonad diambil dari kolam pemeliharaan induk secara hati-hati kemudian dipegang menggunakan kain dengan lubang genital menghadap ke atas. Ikan kemudian di stripping dan sperma yang keluar dihisap dengan spuit plastik $1 \mathrm{ml}$ kemudian dilakukan pemeriksaan sperma segar

\section{c. Pemeriksaan Sperma Segar Sebelum Proses Pembekuan.}

Penentuan kualitas sperma segar yang diperoleh dapat dilakukan pemeriksaan secara makrokopis dan mikrokopis. Pengamatan yang dilakukan sebagai berikut warna, volume dan pH-nya, serta dihitung konsentrasi spermatozoa, motilitas, lama gerak serta viabilitas dari semen segar.

1 Pemeriksaan Makrokopis

a) Pemeriksaan Fisik

Sperma ikan yang tertampung dapat diamati secara seksama mulai dari warna, volume, bau dan kekentalan.

\section{b) Pemeriksa Kimia}

Pemeriksaan sperma secara kimia meliputi derajat keasaman. Menentukan derajat keasaman pada sperma segar menggunakan $\mathrm{pH}$ paper (Rustidja, 2000).

2 Pemeriksaan Mikrokopis

\section{a) Penghitungan Konsentrasi Sperma Dengan Metode Thoma}

Penentuan konsentrasi spermatozoa dapat dilakukan dengan cara thoma dan dinyatakan dalam angka (Salisbury dan VanDemark, 1985). Cara ini menggunakan pengencer berupa larutan eosin dalam $\mathrm{NaCl} 3 \%$. $\mathrm{NaCl} 3 \%$ berfungsi untuk mematikan spermatozoa, sedangkan eosin $2 \%$ berfungsi untuk memberikan warna pada sperma yang mati sehingga dapat menghitung spermatozoa dengan mudah.

\section{b) Viabilitas}

Penentuan nilai viabilitas dapat dilakukan dengan metode pembuatan preparat ulas dengan pewarnaan eosin negrosin. Penghitungan menggunakan konsentrasi sperma dapat dihitung dengan menggunakan rumus (Evans dan Maxwell, 1987 dalam Hidayaturrahmah, 2007):

Konsentrasi sperma $(\%)=$

$\sum$ sperma hidup x $100 \%$

$\sum$ total sperma

Sperma yang mati akan menyerap zat warna merah karena permeabilitas dinding selnya telah melemah, sehingga zat warna eosin negrosin akan dapat masuk ke dalam sel sehingga menyebabkan warna merah sampai kedalam sel terutama pada bagian ujung kepala dan yang hidup akan tetap berwarna putih pada bagian dalam selnya.

c) Lama Gerak

Pelaksanaan pemeriksaan lama gerak dilakukan setelah sperma yang sudah di teteskan pada objek glass ditambahkan aquades, secara alami akan terjadi pergerakan sperma. Penghitungan waktu lama gerak sperma dilakukan sesaat setelah penambahan air,dengan mengamati beberapa sel sperma mulai dari bergerak sampai berhenti dan tidak ada gerakan lagi. Pemeriksaan ini dilakukan pada mikroskop dengan perbesaran 400x (Nuryadi dan Sidiq, 2002).

d) Motilitas

Meneteskan sperma ikan komet sebanyak 2-3 tetes diatas objek glass kemudian tambahkan aguades dan amati pergerakan sperma di bawah mikroskop dengan perbesaran 400x.

d. Pencampuran Sperma Dengan Ekstender

Ekstender madu dibagi menjadi 3 bagian: A1, A2 dan B1, sedangkan A1 dan A2 berisi ekstender madu dan (B1) berisi ekstender madu dan gliserol. Pencampuran sperma dengan ekstender A1 diberikan pada suhu kamar 20- 
$23^{0} \mathrm{C}$ dengan perbandingan $1: 1$. Pencampuran sperma dan ekstender pada suhu kamar dimaksudkan agar suhu antara ekstender dan kondisi normal ikan tidak berbeda jauh. Tahap pencampuran ekstender A2 dilakukan pada cool top cabinet dengan suhu $12^{\circ} \mathrm{C}$ hingga volume sperma, ekstender A1 dan A2 mencapai volume $1 \mathrm{ml}$ dilakukan selama 30 menit. Tahap pencampuran selanjutnya ekstender B1 dengan suhu cool top cabinet $3^{0} \mathrm{C}$ dan dengan volume B1 sebanyak $1 \mathrm{ml}$. (Zenichori dkk, 2007).

e. Evaluasi Sperma Setelah Proses Pencampuran

Semen yang sudah mengalami proses pencampuran dilakukan evaluasi terlebih dahulu sebelum dibekukan. Evaluasi sperma ini meliputi pemeriksaan secara mikrokopis (lama gerak dan motilitas) adapun cara kerja dapat dilihat pada pemeriksaan awal (Zenichori dkk, 2007).

f. Pengisian Sperma Yang Sudah Dievaluasi Ke Dalam Straw

Mini straw yang akan digunakan disterilisasi terlebih dahulu dalam $U V$ Ray sterilizer selama 15 menit. Sperma yang sudah mengalami proses pencampuran dimasukkan ke dalam mini straw dengan menggunakan spuit dalam cool top cabinet. Kemudian salah satu ujung mini straw ditutup dengan kapas steril dan sperma yang sudah diencerkan dimasukkan pada ujung mini straw lainnya kemudian tekan dengan pinset yang telah dipanaskan pada bunsen (Puspitasari, 2006).

\section{g. Proses Adaptasi (Equalibrasi)}

Proses adaptasi dilakukan setelah proses pencampuran dan pengemasan dalam straw selesai, kemudian dibiarkan dalam rak cool top cabinet bersuhu $3^{\circ} \mathrm{C}$ selama 1 jam (Zenichori dkk, 2007).

h. Pra Freezing dan Freezing

Proses pembekuan menggunakan nitrogen cair. Teknik pembekuan terdiri dari 2 tahapan: tahap pertama pra pembekuan yaitu sperma dibekukan pada suhu $-140^{\circ} \mathrm{C}$ dengan jalan memindahkan rak yang berisi mini straw dari cool top cabinet ke dalam uap di atas cairan nitrogen di dalam container dan dibiarkan selama 9 menit. Tahap kedua pembekuan yaitu dengan cara memindahkan mini straw dari uap nitrogen cair ke dalam nitrogen cair bersuhu $196^{\circ} \mathrm{C}$ dalam container (Zenichori dkk, 2007).

\section{i. $\quad$ Thawing}

Mengambil sperma beku yang sudah dikemas dalam bentuk mini straw dari container satu per satu menggunakan pinset kemudian segera direndam ke dalam air yang bersuhu 37$38^{\circ} \mathrm{C}$ selama 10 detik, selanjutnya mengeringkan straw dengan tissue. Memotong straw hendaknya di bagian tengah-tengah lalu meneteskan di objek glass yang telah dihangatkan dan kemudian diperiksa di bawah mikroskop (Zenichori dkk, 2007).

j. Pemeriksaan Kualitas Sperma Setelah Pembekuan

Pemeriksaan ini bertujuan untuk mengetahui bagaimana kondisi spermatozoa. Pemeriksaan ini dilakukan dengan cara thawing spermatozoa dengan waktu thawing 15-30 detik. Pemeriksaan ini meliputi pemeriksaan makrokopis dan mikrokopis. Pengamatan dilakukan selama tiga hari dengan interval pengamatan satu hari atau 24 jam sekali.

\section{Parameter Pengamatan}

Parameter utama dalam penelitian ini adalah viabilitas (\%), dan motilitas (detik). Parameter pendukung yang juga diamati dalam penelitian ini adalah warna, volume, kekentalan dan derajat keasaman $(\mathrm{pH})$.

\section{Analisis data}

Analisis data penelitian secara statistik dengan menggunakan Analisis Ragam (ANOVA) sesuai dengan rancangan yang digunakan yaitu Rancangan Acak Lengkap (RAL) dan untuk mendapatkan perlakuan terbaik dilakukan Uji Jarak Berganda Duncan taraf signifikansi 5\% (Kusriningrum, 2008).

\section{Hasil dan Pembahasan}

Hasil pemeriksaan makrokopis dan mikrokopis sperma segar ikan komet (Carasius auratus auratus) dapat dilihat pada tabel 1 di bawah ini:

Tabel 1. Pemeriksaan makrokopis dan mikrokopis sperma segar.

\begin{tabular}{|l|l|c|}
\hline No & \multicolumn{1}{|c|}{ Pengamatan } & Keterangan \\
\hline 1 & Volume & $1 \mathrm{ml}$ \\
2 & Warna & Putih susu \\
3 & Ph & 7,4 \\
4 & Kekentalan & Kental \\
5 & Konsentrasi & $163,4 \times 10^{6}$ \\
6 & Motilitas (gerakan) & $60 \%$ \\
7 & Viabilitas (\%) & $89 \%$ \\
8 & Lama gerak (menit ) & 3 menit 48 detik \\
\hline
\end{tabular}

Berdasarkan Tabel 1, pemeriksaan motilitas, viabilitas dan lama gerak sperma ikan komet (Carasius auratus auratus) tersebut layak digunakan untuk proses pembekuan.

\section{Viabilitas Sperma}

Penentuan viabilitas sperma dilakukan dengan metode pembuatan preparat ulas dengan 
pewarnaan eosin negrosin. Sperma yang mati, akan menyerap zat warna sedangkan yang hidup tidak menyerap zat warna, adapun rumus penghitungan dapat dilihat pada halaman 26. Rata-rata viabilitas sperma ikan komet pada pengamatan jam ke 72 dapat dilihat pada Tabel 4.

Tabel 2. Rata-rata viabilitas Sperma Ikan Komet Pengamatan Pada Jam Ke 72

\begin{tabular}{|c|c|}
\hline Perlakuan & $\begin{array}{c}\text { Rata-rata } \\
\text { viabilitas }\end{array}$ \\
\hline A & $59,6^{\mathrm{b}}$ \\
B & $48,8^{\text {cd }}$ \\
C & $39,4^{\mathrm{e}}$ \\
D & $63,89^{\mathrm{b}}$ \\
E & $48,34^{\mathrm{cd}}$ \\
KN & $44,76^{\mathrm{e}}$ \\
KF & $44,07^{\mathrm{e}}$ \\
KG & $53,08^{\mathrm{c}}$ \\
KT & $70,18^{\mathrm{a}}$ \\
\hline
\end{tabular}

Keterangan : Superskrip berbeda dalam satu kolom menunjukkan perbedaan yang nyata $(\mathrm{p}<$ $0,05)$.

Hasil Uji Jarak Berganda Duncan menunjukkan perlakuan madu $0,6 \%$ (D) nilai rata-rata viabilitasnya tertinggi dibandingkan dengan perlakuan lainnya. Perlakuan D tidak berbeda nyata dengan perlakuan madu $0,3 \%$ (A) tetapi berbeda nyata dengan kontrol Tris Aminomethane (KT), perlakuan B,C,E dan kontrol $\mathrm{KG}, \mathrm{KF}, \mathrm{KN}$. Rata-rata viabilitas sperma terendah didapat pada perlakuan madu $0,5 \%$ (C) yang tidak berbeda nyata dengan kontrol $\mathrm{NaCl}$ dan kontrol $\mathrm{NaCl}+$ fruktosa $(\mathrm{KF})$ tetapi berbeda nyata dengan semua perlakuan.

\section{Lama Gerak}

Hasil pengamatan penelitian lama gerak spermatozoa diperoleh dari pengamatan berapa lama (detik) sperma dapat bergerak (motil). Rata-rata lama gerak sperma pengamatan pada jam ke 72 disajikan pada Tabel 3 dan Tabel lama gerak disajikan pada gambar 8.

Tabel 3. Rata-rata Lama Gerak Sperma Ikan Komet Pengamatan Pada Jam Ke 72

\begin{tabular}{|c|c|}
\hline Perlakuan & Rata-rata lama gerak \\
\hline A & $65,33^{\mathrm{de}}$ \\
B & $87,33^{\mathrm{ab}}$ \\
C & $59,67^{\mathrm{de}}$ \\
D & $101,33^{\mathrm{a}}$ \\
E & $49,66^{\mathrm{e}}$ \\
KN & $28,33^{\mathrm{e}}$ \\
KF & $79,67^{\mathrm{bc}}$ \\
KG & $72^{\mathrm{cd}}$ \\
KT & $79^{\mathrm{a}}$ \\
\hline
\end{tabular}

Keterangan : Superskrip berbeda dalam satu kolom menunjukkan perbedaan yang nyata $(\mathrm{p}<$ $0,05)$.

Hasil Uji Jarak Berganda Duncan menunjukkan bahwa rata-rata lama gerak tertinggi pada perlakuan madu terlihat pada perlakuan madu dengan dosis $0,6 \%$ (D). Perlakuan D tidak berbeda nyata dengan perlakuan madu $0,4 \%$ (B) tetapi berbeda nyata semua kontrol ( $\mathrm{KN}, \mathrm{KF}, \mathrm{KG}$ dan $\mathrm{KT})$ dan perlakuan madu $0,3 \%, 0,5 \%, 0,7 \%$ (A, C, E). Rata-rata lama gerak sperma terendah didapat pada kontrol $\mathrm{NaCl}$ fisiologis tanpa penambahan (KN) yang tidak berbeda nyata dengan perlakuan madu $0,7 \%$ (E) tetapi berbeda nyata dengan perlakuan lainnya.

Berdasarkan hasil pemeriksaan secara mikroskopis semen segar ikan komet memiliki nilai viabilitas sperma yang cukup baik yaitu $89 \%$, dengan viabilitas yang hidup tersebut dapat dikatakan bahwa sperma yang tertampung cukup baik dan dapat dilakukan ke proses pembekuan selanjutnya. Hal ini sesuai dengan yang dipersyaratkan oleh Stoss (1982) dalam Rustidja (2000) bahwa sperma segar yang akan digunakan untuk penyimpanan dan pembekuan harus mempunyai nilai viabilitas minimal $70 \%$. Konsentrasi sperma sangat penting untuk diketahui karena merupakan salah satu kriteria dalam penentuan kualitas sperma. Konsentrasi yang didapat pada saat penelitian $163,4 \times 10^{6}$ $\mathrm{sel} / \mathrm{ml}$.

Motilitas adalah daya gerak sel sperma yang dinilai segera setelah proses penampungan selesai, yang merupakan kriteria utama dalam penilaian kualitas sperma untuk proses selanjutnya. Nilai motilitas individu yang didapat adalah $60 \%$ sedangkan nilai motilitas massa didapat nilai +++ diamana pergerakannya terlihat bergelombang besar,banyak dan aktif. Hal ini juga diperkuat oleh Toeliher (1981) yang menyatakan syarat sperma yang baik dan dapat dilanjutkan ke proses pembekuan adalah sperma yang memiliki nilai motilitas individu di atas $50 \%$ dan bergerak progresif. Pengamatan lama gerak dilakukan seiringan dengan pengamatan motilitas sperma (gerakan massa dan individu). Dari pengamatan yang dilakukan lama gerak sperma segar adalah 3 menit 48 detik. Lama gerak tersebut dapat dikatakan bahwa sperma tersebut layak untuk dilakukan pembekuan. Fujaya (2002) menyatakan bahwa sebagian besar sperma ikan air tawar dapat bergerak selama 2-3 menit setelah bersentuhan dengan air.

Hasil evaluasi pengamatan semen segar menunjukan bahwa semen segar tersebut 
layak untuk proses pembekuan selanjutnya. Pemeriksaan yang akan dilakukan setelah proses pembekuan meliputi: viabilitas dan lama gerak. Viabilitas spermatozoa adalah salah satu penilaian untuk menentukan kualitas sperma dalam proses penyimpanan untuk fertilisasi buatan (Toelihere, 1981). Jumlah spermatozoa yang hidup dapat digunakan sebagai indikator dalam menentukan kualitas semen. Rata-rata viabilitas sperma terbaik didapat pada perlakuan D. Namun perlakuan D tidak berbeda nyata dengan konrol Tris Aminomethane dan perlakuan A, tetapi berbeda nyata dengan perlakuan lainnya. Hal ini berarti bahwa madu dapat menggantikan pengencer Tris Aminomethane. Dikarenakan madu mengandung glukosa dan fruktosa yang setara dengan pengencer Tris Aminomethane sehingga dapat sebagai sumber energi. Hidayaturrahmah (2007) menyatakan bahan utama yang dipakai spermatozoa sebagai sumber energi pada saat diluar testis adalah fruktosa. Fruktosa diubah menjadi asam laktat dengan bantuan enzim fruktolisin dalam proses glikolisis untuk menghasilkan ATP dan ADP bagi spermatozoa, sedangkan Tris Aminomethane mengandung banyak sumber energi yang berasal dari asam sitrat, laktosa, raffinosa dan kuning telur.

Rata-rata viabilitas sperma terendah didapat pada perlakuan $\mathrm{C}$ yang tidak berbeda nyata dengan Kontrol $\mathrm{NaCl}$ dan kontrol $\mathrm{NaCl}+$ fruktosa $(\mathrm{KN}, \mathrm{KF})$. Kontrol $\mathrm{NaCl}$ menunjukan nilai rendah karena dalam perlakuan ini sperma kekurangan sumber energi yang berasal dari bahan pengencer sehingga viabilitas sperma rendah.

Sperma ikan motil pada saat tercampur dengan media air yang hipotonis, pengamatan lama gerak dimulai dari bergeraknya sperma pada media air hingga sperma berhenti bergerak. Perlakuan D menunjukan hasil tertinggi diantara perlakuan madu lainnya namun perlakuan D tidak berbeda nyata dengan kontrol Tris Aminomethae. Hal ini berarti bahwa ekstender madu dapat menggantikan atau setara dengan pengencer Tris Aminomethane. Adapun perlakuan madu dapat mengganti pengencer Tris dikarenakan didalam Tris terdapat kandungan kuning telur yang berfungsi mencegah dari cold shock, sedangkan pada madu terdapat kandungan glyserol yang berfungsi sebagai zat anti beku atau zat pelindung dari cold shock.

Rata-rata lama gerak sperma terendah didapat pada perlakuan kontrol $\mathrm{NaCl}$ fisiologis tanpa penambahan $(\mathrm{KN})$ disebabkan pada kontrol KN tidak banyak mengandung sumber energi sehingga sperma tidak dapat hidup lebih lama dan apabila dapat hidup sperma akan bergerak dalam waktu yang singkat. Menurut Suquest (1994) dalam Hidayaturrahmah (2007) menyatakan bahwa durasi motilitas terjadi dalam periode yang sangat pendek pada ikan air tawar, Pergerakan aktif spermatozoa ikan sekitar 1-2 menit dan tak ada lagi pergerakan setelah 5 menit.

\section{Kesimpulan}

Penambahan ekstender madu dapat meningkatkan motilitas dan daya hidup spermatozoa ikan komet (Carassius auratus auratus) selama proses pembekuan.

Penambahan ekstender madu dengan dosis $0,6 \%$ merupakan dosis yang terbaik dalam meningkatkan motilitas dan daya hidup spermatozoa ikan komet (Carassius auratus auratus).

Perlu dilakukan penelitian lebih lanjut untuk mengetahui kemampuan spermatozoa dalam proses fertilisasi setelah proses penyimpanan.

Perlu dilakukan penelitian dengan menggunakan ekstender yang lain.

\section{Daftar Pustaka}

Billard R., J. Cosson, G. Perchec and. O. Linhart. 1995. Biology of Sperm and Artificial Reproduction in Carp. Aquaculture vol. 129 : 95-112.

Direktorat Jenderal Peternakan. 2007. Petunjuk Teknis Produksi dan Distribusi Semen Beku. Departeman Pertanian Direktorat Jendral Perternakan. Jakarta. hal 531-536.

Evans. G, Maxwell WMC.1987. Salamon's Artificial Insemination of Sheep and Goats. London: Butterworths. pp 85-141.

Fujaya, Y. 2002. Fisiologi Ikan. Proyek Peningkatan Penelitian Pendidikan Tinggi Direktorat Jendral Pendidikan Tinggi. Departemen Pendidikan Nasional. Jakarta. Hal. 160-163.

Handayani,S. 2004.Penggunaan DMSO dan Glyserol 5,10,15 \% terhadap Kualitas Sperma Pada Kriopreservasi Semen Ikan Batak (Tor Soro). Fakultas Perikanan dan Ilmu Kelautan. Institusi Pertanian Bogor. hal 14-16.

Harper, H. A., P. A. Mayes, D. K. Graner, V. W. Rodwell and D. W. Martin. 1984. Review of physiology Chemistry, $19^{\text {th }}$. Ed. Diterjemahkan oleh Darmawan. Buku Kedokteran, ECG. Jakarta. hal. 164-175.

Hidayaturrahmah. 2007. Waktu Motilitas dan Viabilitas Spermatozoa Ikan Mas (Cyprinus carpio L) Pada Beberapa 
Konsentrasi Fruktosa. Jurnal Bioscientiae. hal 9-18.

Kilawati, Y. 2004. Kualitas Sperma Ikan Mas (Cyprinus carpio) pada Umur Ikan Yang Berbeda. Artikel Ilmiah Tesis. Program Pasca Sarjana. Universitas Brawijaya. Malang. hal 5.

Kusriningrum,R.S. 2008. Perancangan Percobaan. Airlangga University Press. Surabaya. hal 43-87.

Nuryadi dan Siddiq, 2002. Teknik Inseminasi Buatan. Balai Inseminasi Buatan Singosari. Malang. Hal 10-16.

Partodiharjo,S.1992. Ilmu Reproduksi Hewan. Jurusan Reproduksi. Fakultas Kedokteran Hewan Institut Pertanian Bogor. Penerbit Mutiara Sumber Widya. Jakarta.hal 519571.

Puspitasari, R. 2006. Pengaruh Penambahan Glukosa pada Media Ekstender dalam Proses Penyimpanan Sperma Beku Terhadap Kualitas Sperma Ikan Patin (Pangasius suchi). Fakultas Perikanan. Universitas Brawijaya. Malang. hal 16-25.

Rustidja. 2000. Prospek Pembekuan Ikan. Fakultas Perikanan Brawijaya. Malang. hal 46-52.

Salisbury, G. W. and N.L. Van Demark. 1985. Fisiologi dan Inseminasi Buatan pada Sapi. Fakultas Peternakan Universitas Jendral Sudirman. Gajahmada University Press. Hal 124-189.
Shiantiningsih, Dini. 2005. Pengaruh Penambahan Glukosa Pada Proses Penyimpanan Terhadap Motilitas dan Lama Hidup Spermatozoa Ikan Mas. Skripsi. Fakultas Kedokteran Hewan Universitas Airlangga Surabaya. Tidak Diterbitkan. hal 46.

Stoss, J. and Donaldson. 1982. Preservation of Fish Gametes. Proceeding of The International Symposium on Reproductive Physiology of Fish, Centre for Agricultural Publishing and Documentation. Wagenigen, Netherland. pp 114-122.

Toelihere, M.S. 1981. Inseminasi Buatan pada Ternak, Angkasa. Bandung. hal 43-98.

Wulandari, W. 2004. Lama Hidup Spermatozoa Kambing Peranakan Ettawa pada Beberapa Kadar Glukosa dalam Pengencer Larutan Ringer - Kuning Telur Yang Disimpan pada Suhu $5^{\circ} \mathrm{C}$. Skripsi. Fakultas Kedokteran Hewan. Universitas Airlangga. Surabaya. hal 50.

Zaenab, S. 2007. Motilitas Spermatozoa dalam Berbagai Pengencer dan Krioprotektan pada Proses Kriopreservasi. Thesis. Universitas Airlangga. Surabaya. hal 72.

Zenichori, K.Herliantien., dan Sarastina. 2007. Teknologi Prosesing Semen Beku Pada Sapi. Balai Besar Inseminasi Buatan Singosari. Malang. 2007. hal 19-55. 